\title{
Environmentální výchova v předškolním vzdělávání - hledání optimální podoby
}

\author{
Kateřina Jančaříková, Magdalena Kapuciánová \\ Envigogika 2012/VII/1- Recenzované články/ Reviewed Papers \\ Publikováno/Published 31. 05. 2012 \\ DOI: http://dx.doi.org/10.14712/18023061.71
}

\begin{abstract}
Abstrakt:
Příspěvek navazuje na předchozí publikace obou autorek (Jančaříková, 2008, Kapuciánová, 2010) a je zaměřen na environmentální výchovu v MŠ. Jeho cílem je poskytnout učitelkám MŠ oporu při realizaci EVVO. Podnětem pro jeho vznik byly rozhovory $\mathrm{s}$ učitelkami $\mathrm{z}$ mateřských škol uskutečněné na přednáškách a seminář́ch. Učitelky na nich opakovaně upozorňovaly na nedostatek komplexně pojatých podkladů pro realizaci EVVO. Rešeršní část je věnována EV v MŠ $v$ zahraničí i u nás; poukazuje na zjištěnou nedostatečnou pozornost výzkumných pracovníků environmentální výchově v předškolním věku (Davis, 2009) a zároveň popisuje jisté zlepšování situace v několika posledních letech. Výstupem zde prezentovaného kvalitativního šetření (využívajícího vybrané nástroje zakotvené teorie) jsou navržená kritéria realizace a autoevaluace environmentální výchovy $v$ předškolním vzdělávání $v$ Česku. Tento materiál mohou učitelky okamžitě použít v praxi (úprava ŠVP PV, vytvoření nástroje evaluace, resp. autoevaluace). Může sloužit také jako východisko pro odbornou diskusi cílů, obsahu, podmínek vyučování, prostředků, metod i kompetencí učitelek (učitelů).
\end{abstract}

Klíčová slova: předškolní vzdělávání; EVVO

\section{Abstract:}

Contribution builds on the previous publication of both authors (Jančaříková, 2008, Kapuciánová, 2010) and is focused on environmental education in nursery schools. Its objective is to provide support in the implementation of environmental education (EE) to nursery school teachers. Impetus for its creation were interviews with teachers from kindergartens carried out on lectures and seminars. The teachers repeatedly stress the lack of a comprehensive focus of the documentation for the implementation of preschool EE. Part of the research is devoted to the EE in the nursery schools abroad and in Czech republic. Points out the lack of attention of researchers, environmental education in preschool age (Davis, 2009) and also describes some improvement of the situation in recent years.

The output presented here as a qualitative investigation (using the selected instruments enshrined the Grounded theory) proposed criteria for the implementation of the autoevaluation and the environmental education in pre-school education in the Czech Republic. In total, approximately 100 criteria were laid out. It was broken down into categories (areas) and subcategories and are presented in a separate document the key areas and criteria for the implementation of the EE in pre-school age in the chapter of results. The first area is focused on the child (children) and is to be on the development of 
environmental sensitivity training, learning patterns, the development of research skills, involvement in the sustainable life. The second area concerns the person educationers, especially the nursery school teachers, but leaves a space for reflection on the importance of parents and other adults. The third area focuses on the influence of the environment, is broken down into subcategories of the garden (or the nearest outdoor) of the nursery and the indoor environment of the nursery school. The material presented here can be used immediately in practice teachers (edit nursery school curriculum, creating tools, evaluation, or autoevaluation). It may serve also as a basis for technical discussion of the objectives, content, conditions of teaching, resources, methods and competences of teachers (teachers).

\section{Key words:}


Připsáno památce Emilie Strejčkové

\section{Úvod}

Školský zákon přijatý v roce 2004 s účinností od 1. ledna 2005 oficiálně završil českou kurikulární reformu, která byla započata v roce 2001 přijetím tzv. Bílé knihy. Pro každý obor vzdělávání v základním a středním vzdělávání a pro předškolní, základní umělecké a jazykové vzdělávání byly vydány rámcové vzdělávací programy. Rámcové vzdělávací programy (RVP) vymezují povinný obsah, rozsah a podmínky vzdělávání, jsou závazné pro tvorbu školních vzdělávacích programů, hodnocení výsledkư vzdělávání dětí a žáků, tvorbu a posuzování učebnic. v Rámcovém vzdělávacím programu pro předškolní vzdělávání (RVP PV) je jmenováno pět vzdělávacích oblastí (biologická, psychologická, interpersonální, sociálně kulturní a environmentální), které jsou nazvány: "Dítě a jeho tělo", "Dítě a jeho psychika", „Dítě a ten druhý", „Dítě a společnost", "Dítě a svět". Environmentální aktivity mohou být realizovány ve všech jmenovaných oblastech, nejvíce pozornosti je jim obvykle věnováno ve vzdělávací oblasti "Dítě a svět". RVP PV stanovuje dílčí vzdělávací cíle (konkrétně "co pedagog u dítěte podporuje"), dále vzdělávací nabídku ("co pedagog dítěti nabízí), očekávané výstupy a upozorňuje i na rizika, která ohrožují úspěch vzdělávacích záměrư pedagoga. Podle RVP PV by se jednotlivé vzdělávací oblasti měly vzájemně prolínat (Jančaříková, 2010).

Stačí učitelům RVP PV z roku 2004, kurikulum předškolní výchovy Rok v mateřské škole z roku 1998 a dřive vydané Programy výchovné práce z roků 1945, 1953, 1955, 1960, 1963, 1967, 1976, 1978, 1984 jako vodítko pro kvalitní realizaci environmentální výchovy? Studie, která by se zabývala touto otázkou, neexistuje. Nicméně na přednáškách a setkáních s učitelkami mateřských škol se velice často setkáváme s tím, že mnohé z nich hledají a žádají více propracované podklady. Tento příspěvek je tedy jakousi reflexí na potřeby a poptávku učitelek MŠ. Jeho cílem je poskytnout při realizaci EVVO oporu těm učitelkám MŠ, které ji potřebují. Neklade si za cíl hodnocení RVP PV ani hledání příčin toho, proč učitelky vyjadřují výše popsanou potřebu.

\section{Situace v zahraničí}

V zahraničí není environmentální výchově v předškolním vzdělávání věnována taková pozornost, jakou by si zasloužila. Reid a Scott označili nedávno předškolní vzdělávání jako "bílé místo" (mezeru) ve výchově k udržitelnému rozvoji, resp. v environmentálním vzdělávání. a vyzývali badatele, aby sebrali odvahu a toto bílé místo začali zkoumat (Reid, Scott, 2006). v návaznosti na ně udělala Davisová průzkum publikovaných odborných článků s EVVO či VUR tématikou ve 14 časopisech (s impact faktorem). a zjistila, že tématu předškolní EV, resp. VUR se věnuje jen $5 \%$ odborných článků vydaných za sledovaných 12 let (1996-2007).

Davisová dále analytickými metodami nalezené články vyhodnotila. Zjistila, že většina $z$ nich se věnuje studiu vztahů dětí předškolního věku $k$ přírodě (vzdělávání v prírodě), často jsou to články věnované tomu, jak pobyt v prrírodě posiluje zdraví dětí nebo jejich schopnost spolupráce. Dále, že se často objevují články, které kladou do souvislosti pobyt dětí $v$ prírodě a nízký výskyt kriminality v budoucnosti. Několik málo článků je věnováno studiu toho, zda si děti uvědomují (a do jaké míry) environmentální témata (vzdělávání o životním prostředí). Jeden se věnoval tématu studium předškolních dětí jako nositelư změn v životním prostředí (vzdělávání pro životní prostředí). Zásadní témata, včetně výzkumně podloženého vývoje ucelené koncepce environmentálního vzdělávání v předškolním věku, nenalezla. (Davisová, 2009)

Davisová ovšem nezmiňuje Environmentální program pro rané dětství - zásady pro dokonalost, program, který o rok později vydala Severoamerická asociace pro environmentální vzdělávání. Environmentální program pro rané dětství - zásady pro 
dokonalost (NAAEE, 2010) je součástí série dokumentů publikovaných jako součást Národního projektu pro excelentní environmentální vzdělávání. Zásady NAAEE zahrnují doporučení pro kvalitní realizaci ekologických výukových programů pro děti (od narození až do věku osmi let, nejvíce jich je pro věk tři až šest let). Zásady NAAEE poskytují nástroj, který může být použit k vytvoření nových programů nebo který může pomoci $v$ inovaci programů stávajících. Program vytyčuje šest klíčových oblastí: Filozofie programu, Vývojově vhodné postupy, Hra a objevování, Rámcový program environmentálního učení, Místa a prostory, Př́prava pedagoga. Pro každou z těchto oblastí jsou uvedeny zásady, každá zásada je doprovázen několika ukazateli ve smyslu "Co je třeba hledat."

Inspiraci pro předškolní pedagogiku mohou přinést výzkumy realizované mezi staršími respondenty. Často kladená výzkumná otázka zní: "Co ovlivnilo dnešní environmenální aktivisty a vưdce, že se jimi stali?" Otázky tohoto typu řeší celá řada výzkumů. Jmenujme z nich alespoň jeden - kvalitativní výzkum provedený autory Arnoldem, Cohenem a Warnerem. Ti uvádějí nejčastěji zmiňované důvody pro pozdější environmentální chování:

- $\quad$ vliv rodičů (zmínilo všech 12 respondentů),

- $\quad$ zkušenosti z pobytu ve venkovním přírodním prostředí (ne všichni respondeni prožili rané dětství v přírodě, ale všichni zmiňují kempy a tábory),

- vliv prátel,

- vliv učitelů,

- mládežnické skupiny,

- environmentální konference,

- zahradničení. (Arnold, Cohen, Warner, 2009)

Významným zdrojem inspirace jsou také lesní mateřské školy. v lesních mateřských školách mají děti unikátní příležitost denního a opakovaného kontaktu dětí s přírodou. Historie lesních mateřských škol pochází ze skandinávských zemí. První lesní školka vznikla $v$ roce 1892. Principy lesních mateřských škol jsou: celoroční pobyt v př́rodě za každého počasí, př́tomnost dvou pedagogư na počet 15 - 20 dětí, dobré oblečení, zdravé stravování, hodně pohybových aktivit a samozřejmě předškolní výchova a vzdělávání. Hra v přírodě u dětí podporuje kreativitu, komunikační schopnosti, plánování, sebedůvěru, vytrvalost, schopnost koncentrace. Prostředí děti inspiruje k tvưrči činnosti a rozvíjení fantazie. Pohyb podmiňuje dobrý rưst a vývoj, protože intenzivní tělesné zatížení zvyšuje tělesnou zdatnost dětí. Ve 20. století vznikaly další lesní mateřské školy, často nezávisle na sobě (ve Velké Británii, Dánsku, Německu, Kanadě, Švýcarsku, Rakousku, Japonsku, Koreji). v posledních několika letech jsou zakládány lesní mateřské školy i u nás. k lednu 2012 pracuje u nás podle principů lesních mateřských škol 33 mateřských škol, občanských sdružení a dětských klubů. (Kapuciánová, 2010)

\section{Situace v ČR}

České učitelky MŠ mají již řadu let k dispozici publikace o environmentální výchově zaměřené na starší věkové kategorie nebo věkově nespecifické (např. Horká, 1996, Máchal, 2000, Burešová, 2007, Činčera, 2007). Některé výstupy, s definovanými znalostmi a dovednostmi, pro základní školu či jejich části pochopitelně Ize transformovat na předškolní věk.

$\mathrm{V}$ poslední době bylo vydáno několik publikací zaměřených na předškolní věk. $\mathrm{v}$ roce 2010 vydalo nakladatelství Raabe publikaciEnvironmentální činnosti v předškolním 
vzdělávání (Jančaříková, 2010). v roce 2012 vydalo nakladatelství Portál publikaciEnvironmentální výchova v mateřské škole (Leblová, 2012). Pravidelně vychází environmentálně laděné aktivity $v$ Raadci předškolního vzdělávání. Raadce po celý rok přináší komplexní metodiku pro učitelky mateřských škol. Obsahuje přehledné, prakticky ověřené náměty na práci s dětmi, v souladu S RVP PV. Dále učitelky MŠ nacházejí podporu na internetových portálech, např. na Metodickém portálu RVP.

Od roku 2007 mají učitelky MŠ možnost se sdružovat v Mrkvičce. Mrkvička (Malá regionální konference ekologické výchovy pro mateřské školy) je dlouhodobý program, který organizují pod záštitou MŠMT střediska ekologické výchovy v jednotlivých krajích, resp. na celorepublikové úrovni. v současné době je v síti Mrkvička zapojeno kolem 600 mateřských škol ze všech 14 krajů ČR. Od roku 2011 je členství v síti otevřeno i mateřským klubům, centrům a také 1. a 2. ročníkům základních škol (Pavučina, 2012). $\mathrm{Na}$ podzim roku 2011 se konala v Toulcově dvoře celostání konference Mrkvičky. Jejími pořadateli byli Sdružení středisek ekologické výchovy Pavučina a ZČ HB Botič. Konference se zúčastnilo asi 140 učitelek mateřských škol ze všech krajů České republiky. Této konferenci předcházela konference iniciovaná Emilií Strejčkovou krátce po sametové revoluci. Právě ona prosazovala mezi kolegy myšlenku, že je nutné se věnovat environmentální výchově $v$ této věkové kategorii a právě ona založila $v$ Toulcově dvoře MŠ Semínko - zařízení zaměřené na EVVO.

MŠ Semínko slouží jako př́klad dobré praxe a pravidelně pořádá pro učitelky MŠ z ČR i ze zahraničí v rámci různých projektů jednodenní prohlídky s výkladem, semináře a také stáže.

Za ministryně Rút Bízkové vznikla mezirezortní Pracovní skupina pro kontakt dětí s př́rodou. Skupina propojovala ministerstva (MŠMT, MŽP, MK, MZd, MZe, MPSV) a odborníky a hledala způsoby, jak dětem $v$ kontaktu s př́rodou pomoci. Činnost skupiny byla ovšem na jaře 2012 ukončena.

V Toulcově dvoře je od roku 2010 realizováno druhé školení koordinátorů EVVO (tzv. Dvěstěpadesátka) pro učitelky MŠ.

Environmentální výchova je dnes zařazena také do vysokoškolské přípravy učitelek mateřských škol na Pedagogických fakultách, a to ve studiu denním, kombinovaném i celoživotním.

\section{Výzkumná část}

Ačkoli je z výše uvedených přehledů zřejmé, že se „bílé místo" na poli EVVO v předškolním vzdělávání začíná zaplňovat, stěžují si učitelky mateřských škol na skutečnost, že se tak děje "chaoticky”, že „nedostaly přehled toho, co by měly všechno dělat". z rozhovorů s nimi vplynula přirozeně výzkumná otázka: "Co všechno by mělo být součástí environmentální výchovy v předškolním vzdělávání?" a následné výzkumné hledání kritérií optimální podoby předškolního vzdělávání. Cílem tohoto šetření je vytvořit seznam kritérií či ukazatelů. Ty uspořádat do logicky provázaných celků tak, aby se v nich učitelky a učitelé MŠ dobře orientovali.

\section{Metodologie}

Pro hledání kritérií optimální podoby environmentální výchovy v předškolním vzdělávání byly zvoleny vybrané nástroje zakotvené teorie (Strauss, Corbin, 1998), konkrétně metoda práce s literaturou, sběr pojmů (pro lepší porozumění českého čtenáře jsou získané pojmy, angl. concepts, v tomto príspěvku označovány jako "kritéria") a metody validizace (validizace $z$ dat, validizace skupinou expertů a validizace $v$ ohniskové skupině). Zakotvená teorie (ZT) je moderní metodou kvalitativního výzkumu. Kvalitativní 
výzkum je druh pedagogického výzkumu rozvíjený od 60. let 20. stol. a je založený na jiných metodologických postupech než výzkum "klasický". Někdy bývá nazýván „postpozitivistický" nebo "naturalistický”. Zdrojem dat je v kvalitativním výzkumu přirozené prostředí. Kvalitativní výzkum klade dưraz na výklad zkoumaných jevư očima samotných aktérů. Záměrem kvalitativního výzkumu je vytvoření komplexního, holistického obrazu o zkoumaném jevu. Získaná data jsou analyzována souběžně s jejich sběrem a analýza dat výzkumný postup ovlivňuje (Strauss, Corbinová, 1999: str. 51, Jančaříková, 2009). Zakotvená teorie používá vlastní terminologie (např. expert v ZT má specifický význam, obdobně jako výše zmíněný pojem).

Za experty ( $v$ pojetí zakotvené teorie) jsou v tomto příspěvku považovány učitelky MŠ Semínko.

Tyto jsou zároveň v denním kontaktu s dětmi předškolního věku, mají vystudovaná četná školení EVVO a zároveň samy EVVO s touto věkovou kategorií řadu let realizují.

Výzkum není v souladu s výše vytyčnými cíli završen vyslovením teorie. Nebyla proto použita celá škála nástrojů, které ZT přináší. To, že v tomto šetření nebyla ZT použita v plné šíři výzkumných nástrojů, je běžný postup. Samotní její autoři o této možnosti badatele informují. Sběr pojmư (kritérií) začal nejprve jako práce s literaturou a písemnými zdroji - níže popsaným postupem byly z již existujících písemných seznamů („Seznam Éček" viz Jančaříková, 2009 a výčet Doporučených očekávaných výstupů pro základní vzdělávání viz Pastorová, 2011) vyčleněny ty pojmy, které Ize uvažovat i pro předškolní věk. Návazně byly tyto vybrané pojmy uspořádávány a doplňovány (sběrem pojmů v terénu čili mezi respondenty - učitelkami a učiteli MŠ).

Při vytyčování kritérií optimální podoby environmentální výchovy v předškolním vzdělávání byly využity:

- dva dokumenty určené pro realizaci environmentální výchovy na prvním stupni ZŠ, konkrétně

- "Seznam Éček" (Jančaříková, 2009) a druhý dokument Doporučené očekávané výstupy průřezového tématu environmentální výchova pro základní vzdělávání (Pastorová, a kol. 2011). z obou materiálů za pomoci 28 učitelek MŠ označeny položky, které se dotýkají, popř. by se mohly týkat, také předškolního věku,

- osobní zkušenost ( $\mathrm{v}$ terminologii zakotvené teorie teoretická citlivost) autorů,

- $\quad$ zkušenosti pěti učitelek MŠ Semínko ( $v$ terminologii zakotvené teorie je můžeme označit jako expertky),

- $\quad$ diskuse kritérií s celkově takřka 70 učitelkami a jedním učitelem z MŠ.

Při vytyčování klíčových oblastí environmentální výchovy v předškolním vzdělávání byla:

- práce s odobrnou literaturou (zde představená kategorizace navazuje především na koncept Reggio Emilia Approach (Malaguzzi, 1994),

- osobní zkušenost ( $v$ terminologii zakotvené teorie teoretická citlivost) autorů,

- diskuse s celkově více než 40 učitelkami a jedním učitelem z MŠ

\section{Krok šetření:}

1. Oba výchozí dokumenty - „Seznam Éček" (Jančaříková, 2009) a prvnímu stupni ZŠ určené Doporučené očekávané výstupy pro základní vzdělávání (Pastorová, a kol. 2011) - byly předloženy skupině 28 učitelek MŠ). Ty podle 
pokynů vybraly (barevně označily ve vytištěných dokumentech) a) položky, které se - podle jejich názoru - dotýkají, popř. by se mohly týkat také předškolního věku (označily je zeleně), b) ty položky, které - podle jejich názoru - nejsou pro předškolní věk vhodné (označily je červeně).

2. Prácebarevně označenými materiály. Do průběžného seznamu byly zařazovány všechny (od alespoň jedné učitelky vybrané) vybrané (označené zeleně) položky. a to vyjma př́padu, kdy jiná učitelka ten samý bod označila červeně. (Červené a zelené označení stejného bodu se tedy vyhodnocovalo jako, kdyby bod označen nebyl. Ovšem pokud bylo zelených více, než červených - byl tento bod do seznamu vybraných zařazen, nejednotnost názorù byla poznamenána a následně byl tento bod probrán s učitelkami/učiteli v ohniskové skupině).

3. Seznam, který vznikl (pracovní verze), byl předložen cílové skupině - 22 učitelkám mateřských škol, účastnicím semináře Mrkvičky, v první ohniskové skupině. Učitelky se vyjadřovalypředloženému materiálu jako celku, ale byly také diskutovány problematické body (viz výše). Na základě jejich podnětů byl materiál dále upraven a mírně rozšířen (bylo doplněno několik pojmů).

4. Tento inovovaný materiál byl předložendiskusi další skupině učitelek, tentokrát 30 studentkám kombinovaného studia oboru předškolní pedagogika PedF UK v Praze. Učitelky-studentky se vyjadřovaly k předloženému materiálu jako k celku. a opět byly diskutovány ony problematické body (viz výše). Na základě jejich podnětů byl materiál opět upraven a rozšíren. s touto skupinou byla také již řešena otázka vhodné kategorizace sebraných pojmů. Učitelky byly seznámeny s členěním, které bylo použito v materiálu Doporučené očekávané výstupy pro zákaldní vzdělávání (Pastorová, 2011) a s konceptem Tři učitelé (Malaguzzi, 1994). Dále byly rozděleny do skupin a vyzvány, aby vytvořily několik modelů (včetně schématu) kategorizace sebraných kritérií. v následné diskusi se celá skupina shodla na jedné upravené variantě.

5. Materiál byl upraven - kritéria byla uspořádána podlepředchozím bodu navrženém způsobu.

6. Následně byl upravený materiál předán expertní skupině (5 učitelek MŠ Semínko). Učitelky si materiál prostudovaly individuálně doma, napsalyněmu poznámky. v expertní ohniskové skupině navrhovaly, a bud' přijímaly, nebo zamítaly změny. Na základě jejich připomínek a návrhů byl vytvořen revidovaný text "Klíčové oblasti a kritéria realizace environmentální výchovy $v$ předškolním věku".

7. Tento materiál byl ověřovándůrazem na zjištění, zda je srozumitelný cílové skupině. Ověření srozumitelnosti probíhalo na semináři s 16 studenty kombinovaného navazujícího magisterského studia oboru předškolní pedagogika (1 učitel a 15 učitelek). Účastníci byli rozděleni do šesti skupin, každá skupina měla za úkol prostudovat jeden celek a seznámit s ním ostatní. Na základě tohoto semináře byly udělány jisté úpravy členění dokumentu.

8. Drobné změny ve formulaci kritérií ijejich kategorizaci byly závěrem ještě naposledy hodnoceny $v$ expertní ohniskové skupině ( 5 učitelek MŠ Semínko).

Níže předložený text Klíčové oblasti a kritéria realizace environmentální výchovy $v$ předškolním věku byl mnohokrát upravován, diskutován a opět několikrát upravován, $a$ to až do zde předložené podoby. v této podobě je poskytnut veřejnosti $k$ dalším připomínkám, kritikám a úpravám. 


\section{Výsledky}

Celkem bylo sebráno a vytvořeno více než 100 kritérií ideální podoby realizace environmentální výchovy. Ta jsou roztříděná do klíčových oblastí (kategorií): Dítě, Učitel a Prostředí. To je nejvýznamnější výstup příspěvku.

Učitelky MŠ, které byly požádány o přečtení pracovní verze Doporučených očekávaných výstupů pro 1. stupeň ZŠ (Pastorová, 2011), označily v materiálech ty, které by bylo možné a vhodné použít, resp. po úpravě použít, i pro potřeby předškolního vzdělávání. Na základě jejich barevného označení v pracovním textu a také při následné diskusi v ohniskové skupině vyplynulo, že požadují, aby se kromě environmentální senzitivity $v$ předškolním věku děti seznamovaly také se základními zákonitostmi a aby děti získávaly výzkumné dovednosti (obojí zeleně označila většina, červeně žádná). Respondentky se ovšem neshodovaly na detailech, např. jaké konkrétní nástroje pozorování mají děti používat. Některé se domnívaly, že by děti neměly používat žádné nástroje pozorování (čili, že by měly provádět pozorování jen vlastními smysly), jiné se domnívaly, že by děti měly používat všechny $v$ uvedeném dokumentu zmíněné nástroje pozorování, včetně mikroskopu (některé učitelky dokonce text okomentovaly poznámkou, že mikroskopy ve třídách mají a používají), lakmusových papírků pro měření pH aj. v následné diskusi vyšlo najevo, že jejich rưzné postoje ovlivnila znalost oboru, vlastní zkušenost (zkušenost z dětství i zkušenost pedagogická), ale i osobnost. i když by některé z oslovených učitelek zařadily témata z okruhư Problémy a konflikty a Akční strategie $i$ do předškolního vzdělávání, po dlouhé diskusi nakonec tato témata zařazena nebyla. Jejich zařazení do ŠVP PV se (vzhledem k očekávané návaznosti na ZŠ) jeví jako předčasné, i když ne nereálné (a jak vyplynulo z diskuse, některé učitelky MŠ skutečně s dětmi pracují i na řešení - vhodně vybraných - environmentálních konfliktů).

Učitelky z první ohniskové skupiny (seminář Mrkvičky v Oldřichově v Hájích) navrhovaly jen drobné změny $v$ seznamu kritérií, ale doporučily změnu struktury textu (jiné, přehlednější uspořádání kategorií). Projevovaly radost, že "konečně někdo vymyslel kritéria, podle kterých by se mohly rídit", což se poněkud komicky projevilo i tím, že odmítly psát vlastní poznámky do připravených formulářù (pracovních verzí materiálu), dokud nedostaly materiály dvakrát (toužily si formuláře odvést nepopsané do svých mateřských škol, aby je mohly namnožit a používat k další práci).

Expertky - učitelky z MŠ Semínko většinu vytvořených kritérií pochválily (například doporučení, aby na zahradě byly také kopřivy, nebo doporučení, aby učitelky kriticky hodnotily např. reklamy). a zásadně vyzdvihly tato kritéria: "děti zažívají legraci”, doplnily "pohodu" a "kamarádství". Dále navrhly osm drobných změn založených na zkušenosti (např. použít v jednom kritériu místo slova "ryba" slovo „pulec”, protože "se děti s pulci setkávají častěji, než s rybou"). Doporučily také používat spojení "výzkumné dovednosti" místo původně navrženého spojení „předvýzkumných dovedností". Všech pět expertek upozorňovalo na kritérium "jsou denně nejméně dvě hodiny venku,.." jako na „v běžné MŠ nereálné, a to z důvodů dopoledních kroužků, dlouhého převlékání dětí a krátkého času mezi svačinou a obědem". Nakonec toto kritérium bylo ponecháno, protože učitelky z jiných MŠ se v následné validizační diskusi vyjádřily, že to reálné je, některé se svou třídou chodí na dvě hodiny denně ven. Na základě zkušeností se školením učitelek z jiných mateřských škol doporučovaly expertky do textu zařadit kapitolu "Co není EVVO" a dále doporučovaly připsat poznámky k některým kritériím (např. v poznámce ke kritériu "zpívají písničky o přírodě..." vyjádřily obavy, aby „si některé učitelky neřekly: „Dnes nepưjdeme ven, zazpíváme si o př́rodě a je splněno EVVO"). Tato kategorie zařazena nebyla, $z$ důvodu toho, že text je laděn pozitivně, jako doporučení, nabídka aktivit. Naopak se ale expertky snažily prosadit do závěrečného textu kritérium „zahrada má dostatečnou rozlohu". To ovšem nakonec po důkladné diskusi zařazeno nebylo, protože není v možnostech učitelek ovlivnit něco tak zásadního, jako je velikost školní zahrady. 
Expertky - učitelky z MŠ Semínko dále upozornily v souvislosti s kritériem „učitelka... děti nepřetěžuje (např. požadavkem na znalost názvư stromů, živočichů, rostlin)", že se tak v běžných MŠ podle jejich zkušeností skutečně někdy děje.

Důležitým průběžným výsledkem bylo (na základě diskusí ve všech ohniskových skupinách) objevení potřeby věnovat se dalším ( $\mathrm{V}$ DOV ZV dle Pastorové a kol. nevytyčeným) okruhům: osobnosti učitelky (učitele) mateřské školy a prostředí, ve kterém se děti pohybují (zahrada, třída) a zapojení dětí do udržitelného života. To nakonec vedlo k využití modelu "tři učitelé" (Malaguzzi, 1994).

Diskutován byl velice také pro rozvoj environmentálních kompetencí významný a nezastupitelný vliv rodičů, prarodičů i dalších členů rodiny. Učitelky $v$ ohniskových skupinách často zmiňovaly rodiče jako zdroj problémů. Někdy jsou jejich zkušenosti s rodiči až neuvěřitelné, např. učitelka z ohniskové skupiny III vypráví: „V září 2011 k nám přišla nová holčička, která se strašně bála v lese. Když jsem zjišt́ovala proč, ukázalo se, že v lese ještě nikdy nebyla. Její maminka se také dost divila, že s dětmi chodíme do lesa. Holčička chodí navlečená celá do růžového, neběhá, nehraje si, jen aby si šatičky neušpinila. Ale pracujeme na tom, maminka už se smířila, že s dětmi do lesa chodit budeme." Na druhou stranu si učitelky MŠ uvědomují i pozitivní vliv rodičů na rozvoj dítěte a respektují ho. v diskusích zmiňovaly rodiny, ve kterých jsou "děti vedeny k lásce k prírodě".

Učitelky si často stěžovaly na to, že rodiče vozí děti do MŠ autem s vytápěním/klimatizací a že děti následkem toho nemají s sebou oblečení odpovídající počasí. To pak vede ke značnému omezení možností pobytu dětí venku. Expertky-učitelky z MŠ Semínko to formulovaly takto: "Rodiče často nevědí, jak děti dobře obléci. Mnohdy neumí ani správně obléci sami sebe." Jedna učitelka z druhé ohniskové skupiny upozorňuje, že spěch rodičů (ale i učitelek) pưsobí kontraproduktivně na rozvoj environmentální senzitivity: „Děti dnes nemají možnost se zastavit u zajímavého objektu a pozorovat ho, stále je někdo někam popohání".

Jedna z učitelek z třetí ohniskové skupiny sdílela nedobrou zkušenost s "lesní mateřskou školou" jedné rodiny, jejíž dítě nyní chodí k ní do třídy. Popisovala ji takto: "Dítě se domů vrátilo úplně mokré, s mokrým oblečením, mokrým spacákem. Učitelka o tom nevěděla nebo rodiče neinformovala. Když matka viděla promrzlé a neštastné dítě, okamžitě ho z lesní MŠ odhlásila a následně ho rodiče umístili k nám - do klasické školky."

Při diskusi ve třetí ohniskové skupině se ukázalo, že takřka všichni respondenti používají při práci s dětmi speciální lupy (tyto lupy bylo možné v roce 2004 zakoupit jen v zahraničí, v MŠ tehdy běžné nebyly) a že přibližně jedna třetina respodentů využívá vzdělávání za pomoci zvířat ( $A A E$, animal assisted education). Expertky - učitelky MŠ Semínko upozorňují, že pokrok v realizaci environmenální výchovy ovšem Ize zaznamenat jen $v$ některých $M S$ a že stále je dost těch, ve kterých není environmentální výchově věnována dostatečná pozornost a nebo (a hưře), ve kterých je environmenální výchova realizována odtrženě od reality, např. "na začátku takové "lekce EVVO" učitelka rozmístí po podlaze třídy makety různých odpadů, např. PETlahve, děti je třídí do maket odpadkových košů".

Učitel a učitelky MŠ ze třetí ohniskové skupiny ověřovali srozumitelnost výsledného materiálu Klíčové oblasti a kritéria realizace environmentální výchovy $\boldsymbol{v}$ předškolním věku. Učitelky a učitel byli rozděleni do šesti skupin. v každé skupině nastudovali část dokumentu a seznámili s ním bez problémů ostatní účastníky. v následné diskusi se vyjádřili, že dokument považují za srozumitelný a užitečný a že ho budou používat při své práci. 


\section{Klíčové oblasti a kritéria realizace environmentální výchovy v předškolním věku}

Dlouhodobým cílem environmentální výchovy je, aby se dnešní děti - až dospějí rozhodovaly pro prírodu (proenvironmentálně). Čili rozvíjet takové jejich kompetence, které směřují (převážně k budoucímu) zodpovědnému proenvironmentálnímu chování. Úkolem environmentální výchovy v MŠ je především děti řádně motivovat, rozvíjet jejich environmentální senzitivitu, seznámit je se základními ekologickými zákonitostmi a také se základními výzkumnými dovednostmi. Průvodcem jim je "trojlístek učitelư" (srovnej s konceptem Třetí učitel, Davisová, 2009), které byly do schématu zachyceny jako "kořeny", a to: rodiče, učitelka a prostředí (Př́roda).

\section{Oblast zájmu: Dítě}

\section{Environmentální senzitivita}

Pro předškolní dítě je středobodem environmentální výchovy rozvoj environmentální senzitivity. Nebo naopak: právě předškolní věk je senzitivním obdobím pro rozvoj environmentální senzitivity. k rozvoji environmentální senzitivity může v dostatečné míre dojít jen ve vhodně členitém prírodním prostředí. Proto je pro potřeby environmentální výchovy kladen velký důraz na prostředí, ve kterém se děti pohybují. Vhodné prostředí rozvíjí osobnostní charakteristiky pro budoucí proenvironmentální chování a poskytuje základ přirozenému celistvému rozvoji dítěte (Jančaříková, 2010 s. 8). Zásadní pro rozvoj environmentální senzitivity je prímý a hojný kontakt s př́rodou, resp. s jejími jednotlivými, konkrétními součástmi. Príroda (resp. její prvky) plní roli tzv. třetího učitele (Malaguzzi, 1994); dochází k informálnímu vzdělávání (Strejčková, 2005). Děti získávají přirozeně velké množství podnětů a zkušeností, pưsobících harmonický rozvoj. a prožívají $v$ prírodním prostředí hezké chvíle. Ty je nutné vhodným způsobem zpracovat, aby se z nich staly zapamatované zážitky. Proto se děti učí prožitky $v$ prírodě reflektovat, vyprávět, výtvarně zpracovat. Proto porovnávají vlastní prríběhy s príběhy ostatních dětí, dospělých osob nebo s př́běhy z knih či se slovy písniček. Proto si prožitky připomínají prostřednictvím výstavek, nástěnek, portfolia. Na rozdíl od gymnaziálního i základního vzdělávání je $v$ předškolním věku nutné věnovat pozornost také pohodlí a naplnění základních potřeb (welfare) dítěte. Těmi jsou dodržování pitného režimu, pocit nasycení, teplotní komfort a také mozkově kompatibilního prostředí (ve smyslu pojetí Kopřivy a kol., 2011). Čili pedagog by se měl snažit o záměrnou minimalizaci nepř́jemných pocitů a nepř́jemných prožitkư $v$ prrírodě, nebot' ty ( $a \quad v$ předškolním věku zvlášt') rozvoj environmentální senzitivity blokují. Žák druhého stupně a určitě středoškolák mưže zpětně pozitivně hodnotit i jistou míru strádání nebo nepohody; předškolák nikoli.

\section{Doporučení pro rozvoj environmentální senzitivity v předškolním věku}

Pro dostatek přímých kontaktů s přírodou a jejími jednotlivými prvky:

- Děti jsou denně nejméně dvě hodiny venku, a to na vhodně koncipované školní zahradě (viz samostatný oddíl níže) nebo ve vhodně vybraném prírodním prostředí. Učí se od přírody (tj. je nastartován proces informálního vzdělávání).

- Děti poznávají vhodně vybrané konkrétní živé tvory a konkrétní biotopy (z okolí MŠ či domova dítěte).

- Děti pečují za pomoci dospělé osoby (učitelky, uklízečky, rodičů) o něco živého (stromek, záhonek, krmítko, drobné zvíře v zájmovém chovu apod.). Učí se živé tvory netrápit, neobtěžovat; kořenový systém rostlin a podhoubí hub neničit.Učí se žít svůj život nejen pro sebe.

- Děti si vytvářejí intenzivní vztah ke konkrétnímu místu nebo stromu. 
- Děti poznávají historii krajiny v okolí MŠ.

- Děti oslavují významné události (např. jubilea, narozeniny, Den Země, dožínky, otevírání studánek) tak, aby se při oslavách rozvíjel jejich vztah k př́rodě.

- Děti si uvědomují definitivnost smrti a konečnost života. Osvojují si úctu k životu v jeho různých formách a stálém obnovování růstu, rození či plození a zániku.

Pro náležitou reflexi prožitků:

- Děti obdivují společně s učitelkou - odbornicí na EVVO (viz samostatný oddíl níže) prrírodu a její součásti. Získávají lásku k přírodě.

- Děti prožívají pěkné vztahy s vrstevníky. Vedeni příkladem kamaráda překonávají př́padné obavy z přírody a jejích součástí. Nebo jsou naopak př́kladem jinému.

- Děti naslouchají příběhům o př́rodě z vhodně vybraných dětských knížek nebo i př́běhům dospělých osob - dobrých vypravěču o prírodě. Osvojují si etiketu posluchače. Učí se vyprávět své vlastní zážitky z prrírody.

- Děti zpívaji písničky o přírodě, naslouchají hudbě o přírodě, učí se naslouchat zvukům přírody a rozeznávat je (zpěv ptáků, praskání šišek, bzučení, šumění apod.).

- Děti poznávají přírodní zákony přirozeně formou vlastní zkušenosti.

- Za pomoci dospělé osoby si děti príležitostně připomínají zážitky z přírody pomocí portfolia nebo nástěnky $\mathrm{s}$ fotografiemi a kresbami, popř. pamětních krabic s kamínky a dalšími drobnostmi z vycházek či pobytů.

- Všechny děti jsou oceněny za aktivitu a práci, i když jejich výtvory a výsledky nejsou dokonalé. Tj. oceněny a vystaveny na nástěnce jsou výkresy a tvorba všech dětí, které se programu zúčastnily, nejen některých.

- Děti si uvědomují, že pocit štěstí není jen materiální podstaty, ale že může přicházet skrze př́ijemné prožitky a přátelství.

Doporučení pro zajištění bezpečí a pocitu pohody:

- Děti zažívají legraci. Realizace EVVO není nudná a nepř́ijemná; vychází z iniciativy a potřeb dětí.

- Děti mají možnost projevovat aktivitu, zvídavost, tvořivost, učí se objevovat.

- Pedagogové se snaží o (alespoň príležitostné) snížení počtu dětí na jednoho dospělého. Vytvárí obohacené prostředí, aby se některé děti zabavily samy a soustředěná pozornost mohla být věnována individuálně.

- Děti hrají vhodné a nesoutěživé (sic!) hry, prosociální hry s prírodní tematikou nebo prímo $v$ prírodě.

- Děti jsou oblečeny a obuty tak, aby stále pocitóvaly tělesnou pohodu, aby netrpěly zimou či vlhkostí ani horkem a aby jim oblečení ani obutí nebránilo v aktivním pohybu a hře.

- Aktivity dětí jsou vhodným způsobem dospělou osobou kontrolovány tak, aby nedošlo ke zranění, ale zároveň nebyla jejich činnost nezdravě omezována.

- Ve třídě ani na zahradě nejsou dětem na dosah smrtelně jedovaté rostliny (např. oleandr, diefenbachie, náprstník nebo tis). 
- Vodní nádrže jsou zabezpečeny, aby nemohlo dojít k utonutí dítěte.

- Děti mají dostatek informací o bezpečných způsobech pohybu a pobytu venku (jak se nezranit, co jíst, co nejíst, jak se neztratit, co dělat, když ...).

- Děti jsou vedeny $k$ samostatnosti (sebeobsluze) a $k$ zodpovědnosi samy za sebe (autoregulaci).

- Děti se učí chránit samy sebe před nepř́znivými dopady znečištěného životního prostředí (kouř cigaret, výfukové plyny, velký hluk, oslnivé světlo apod.). Uvědomují si souvislost mezi kvalitou životního prostředí a zdravím člověka.

- Při aktivitách rizikových (např. posezení u ohně) je zajištěn dostatečný dozor (přítomnost další učitelky, popř. jiné dospělé osoby).

\section{Environmentální zákonitosti}

Poznávání zákonitostí $v$ předškolním věku je důležitou součástí environmentální výchovy. Podle respondentů neexistuje téma, které by nemohlo být $\mathrm{s}$ predškolními dětmi probíráno. Ovšem je vhodné vybírat zákonitosti a témata základní a předávané informace vhodně zjednodušovat. Pro potřeby předškolního vzdělávání byly respondenty vytyčeny tyto oblasti: dítě si uvědomuje existenci potravních řetězců, závislost organismu na prostředí a uvědomuje si tok času a proměny sama sebe a také svého okolí v čase.

Informace a poznatky předávají pedagogové prostřednictvím vhodných didaktických metod (názoru, máňásků či hrou na nápodobu). Věcně zjednodušovat a používat pro předškoláka srozumitelnou řeč dokáže kompetentní učitelka MŠ lépe než většina na daný problém graduovaných odborníků. Ovšem je zřejmé, že učitelka nemůže dosáhnout takové úrovně znalostí, jako oni. Bude se setkávat s otázkami, na které nebude znát odpověd'. $\checkmark$ takových okamžicích by měla zachovávat dvě pravidla:

- Informace podávané dítěti by měly být vždy věcně správné! a jednoduché. Dospělý vybízí dítě, aby na informace reagovalo vyjádřením vlastního názoru získaného zkušeností.

- Pokud dospělý nezná na dětskou otázku odpověd', měl by to přiznat a s dětmi ji pomocí odborníků nebo informačních médií nalézt. Děti potřebují poznávat také cesty získávání informací.

Důležité je také environmentální vzdělávání učitelky MŠ v rámci celoživotního vzdělávání.

\section{Doporučení pro poznávání základních zákonitostí}

- Děti se seznamují s vhodně vybranými modelovými živočichy, rostlinami a houbami.

- Děti poznávají environmentální zákonitosti, např. závislost zvírat i rostlin na prostředí (pulec na suchu lekne, apod.). Postupně a přiměřeně poznávají vhodně vybrané české i světové biotopy a jejich obyvatele.

- Děti pozorují kompost a procesy na něm probíhající. Poznávají, co se v prírodě rozloží, za jak dlouho a co nerozloží.

- Děti si vypěstují rostlinu k jídlu (např. hrášek nebo brambory). Seznamují se s tím, že potraviny jsou připravovány $z$ rostlin, živočichů či hub, tedy že to jsou produkty z prírody.

- Děti si uvědomují potravní vztahy (koloběhy látek a živin). 
- Děti uznávají smysluplnou existenci každého tvora. Nejsou jim předávány seznamy "škưdcư" ani schémata "zviŕat odporných" (pavouci, hadi).

- Děti zažívají pozitivní ekonomický dopad určitých činností (např. dozví se, jak byly využity peníze za sběr papíru).

- Děti vnímají sezónní (roční období) i krátkodobé (počasí) změny a přizpůsobují jim aktivity. Respektují sezónnost vybraných aktivit.

- Děti se seznamují prostřednictvím praktických činností s životem předků (především prarodičů). Vyzkoušejí si jejich nástroje, pracovní postupy a techniky, styly života.

- Děti se seznamují s životem jiných kultur (např. Indiánů, Eskymáků). Vyzkoušejí si některé jejich nástroje, techniky a styly života. Uvědomují si závislost stylu života lidí na podmínkách životního prostředí. a sounáležitost lidí na naší planetě.

\section{Výzkumné dovednosti}

I v mateřské škole můžeme rozvíjet výzkumné (badatelské) dovednosti, a to formou nabídky pro děti se zájmem o tento typ činností. Dítě se seznamuje se svými smysly a jejich čidly a učí se je využívat k pozorování či k experimentování. Poznává základní nástroje pozorování a měěení. Učí se i základům experimentu (odhad, ověření). Mnohé z aktivit děti skutečně baví, Ize očekávat, že takto směřovaná nabídka aktivit usnadní jejich přechod do školy základní.

Doporučení pro rozvoj výzkumných dovedností:

- Děti se učí kriticky myslet, rozlišovat fakta a fikci (např. v pohádkách nebo $v$ televizních reklamách).

- Děti dostávají podněty pro hmat, sluch, chut', čich, tj. nejen pro zrak. Učí se poznávat svět všemi smysly.

- Děti mají dostatek príležitostí k manipulaci s vhodně vybranými pomůckami a nástroji (kuchyňské váhy, plastové pipety, metr, hmoždiřr, nưž, lupa).

- Děti se pod vlídným dozorem dospělé osoby účastní experimentů. Zažívají oceňování vlastních objevů od dospělé osoby. Dětem je formou nabídky umožněno učit se základům vědeckého pozorování (mapování problému, odhad předpokládaného výsledku, pokus, hodnocení, diskuse, závěr a vyhodnocení např. na nástěnce).

- Děti získávají informace z prostředí či krajiny (např. "stromy mají povadlé listy, je sucho, potřebovaly by zalít", "vlaštovky se houfují, zima se bliźíi" apod.).

- Děti vnímají prírodu a přírodní procesy $v$ delších časových úsecích (periodicita ročních období).

\section{Zapojení do udržitelného života}

- Děti se učí sebeobsluze. Podílejí se na životě dospělých a mají dostatek příležitostí sledovat a napodobovat udržitelné chování u učitelky a dalších dospělých osob. $\checkmark$ rámci svých možností se podílí na práci na zahradě nebo ve třídě.

- Doporučení pro zapojení do udržitelného života:

- Děti se přiměřeně podílejí na práci pro př́rodu (pletí, zalévání, krmení zvěře na krmítku či krmelci v zimě, popř. i sběr odpadků apod.). 
- Děti tvoří a pracují při výtvarných činnostech s přírodninami. Vyrábějí z přírodních materiálů (např. vánoční a velikonoční ozdoby či hračky).

- Děti se seznamují s tradičními postupy při úpravě či čištění šatstva (např. bělení na slunci), nádobí (např. pomocí octa) či pracovních ploch (např. pomocí kuchyňské soli).

- Děti se podílejí na úpravách okolí MŠ (hrabání listí, péče o studánku apod.) zúčastní se brigády s rodiči.

- Děti mají možnost podílet se na prípravě pokrmů současnými i tradičními způsoby (např. pučálka, jáhlová kaše).

- Děti šetří potravinami, i když jich je nadbytek, uvědomují si, že jiní (lidé i zviŕata) mají i dnes hlad.

- Děti používají také staré, zděděné věci (oblečení, pomůcky i hračky). Vypráví přiběhy některých rodinných "dotýkaných" věcí, vědí, kdo a jak je používal, od koho je kdo dostal.

- Děti přednostně vybírají na trhu místní výrobky. (Pokud v MŠ není možnost navštěvovat skutečné trhy, Ize nahradit hrou na nápodobu.)

- Děti se setkávají s řemeslníky. Získávají vhled do technologií prípravy (jak se co dělá, co z čeho se vyrábí). Uvědomují si, že potraviny, léky a mnohé užitečné předměty (nábytek) jsou prírodního pùvodu.

- Děti si některé věci umí vytvořit samy.

- Děti si uvědomují, že všechno kolem nich je z prírodních zdrojů, které nejsou obnovitelné, židle, stůl, koberec, auto, počítač i mobilní telefon.

\section{Oblast zájmu: Učitelka (učitel) MŠ}

Učitelka (resp. učitel) je, hned po rodičích a prarodičích, nejvýznamnější osobou, která může ovlivnit kvalitu a efektivitu environmentální výchovy. Měla by být jednak raádně aprobována pro práci s předškolními dětmi a zároveň by měla mít (nebo usilovat o) environmentální vzdělání, např. v rámci celoživotního vzdělávání (existuje celá řada akreditovaných programů a kurzů, nejznámější je tzv. 250tka) nebo v rámci vysokoškolského studia oborů Předškolní pedagogika.

\section{Doporučení:}

- Učitelka (učitel) připravuje aktivity a programy v souladu s poznatky z oboru.

- Učitelka (učitel) navštěvuje EVVO konference a semináře. Seznamuje se s př́klady dobré praxe.

- Učitelka (učitel) upřednostňuje vlastní práci s dětmi, před návštěvami ekocenter a návštěvami lektorù ve tř́dě.

- Učitelka (učitel) poskytuje dětem věcně správné, vhodně zjednodušené a zajímavě podané informace.

- Učitelka (učitel) se nebojí přiznat, že něco neví nebo nezná. Ukáže dětem postup, jak informace vyhledat. 
- Učitelka (učitel) respektuje individuální zvláštnosti osobnosti i vývoje každého dítěte. Děti nepřetěžuje (např. požadavkem na znalost názvů stromů, živočichů, rostlin).

- Učitelka (učitel) podporuje zvídavost, oceňuje aktivitu a tvořivost dětí.

- Učitelka (učitel) aktivně upravuje vnitřní i venkovní prostředí MŠ tak, aby lépe vyhovovalo požadavkům EVVO a UR.

- Učitelka (učitel) zapojuje děti do společné práce. Dbá na sebeobsluhu dětí.

- Učitelka (učitel) kriticky hodnotí informace (např. reklamy) a vhodným způsobem interpretuje dětem.

- Učitelka (učitel) zapojuje rodiče, popř. seniory či veřejnost do života MŠ.

- Učitelka (učitel) do MŠ zve zajímavé osobnosti, organizuje návštěvní programy (např. myslivec, sokolník, apod.).

- Učitelka (učitel) je dětem pozitivním vzorem. Sama sebe pozitivně vnímá a rozvíjí.

\section{Oblast zájmu: Prostředí}

Prostředí je pro environmentální výchovu velice důležité. Jeho význam pro rozvoj environmentální senzitivity není dosud vnímán dostatečně. Prostředí mưže rozvoj environmentální senzitivity podporovat, ale může ho také degradovat. Lidé jsou součástí prostředí, ve kterém žijí. Obvykle si uvědomujeme, že lidé formují krajinu. Málokdo si ale připouští, že krajina na oplátku formuje nás, lidi. Př́rodní prostředí poskytuje přiměřené množství podnětů a nabízí ideální možnosti pro hru i relaxaci. Prostředí prosté na podněty, např. zahrada se zpevněnými povrchy, bez porostu, předškolní dítě deprivuje. Deprivovat mưže i nadbytek podnětů (např. z televizních pořadů). Je zodpovědností dospělých, aby koncipovali zahrady MŠ tak, aby byly pro rozvoj dětí co nejpř́nosnější, a aby objevovali, které prvky děti pritahují a podněcují je kaktivitám a které ne. v přirodní zahradě je nejméně navštěvovanou atrakcí klasická skluzavka. Děti nejčastěji navštěvují "blátoviště" a "vodní prvek". Dokonalá imitace Perníkové chaloupky děti nebaví tak dlouho jako "obyčejný" vrbový domeček (ten totiž poskytuje př́ležitost proměnit se $v$ dětské fantazii ve stovky různých míst, předmětů a zviŕrat). Ve vnitřním prostředí, tedy třídě, by měly převládat př́rodní a obnovitelné materiály (dřevěné hračky, látky), při zařizování by měli dospělí dbát na minimalizaci plastů. To pokud možno i na zahradě (Grundler, Schafer, 2010).

Doporučení pro školní zahradu (popř. pro nejbližší okolí MŠ, pokud je pravidelně využíváno)

Pro diverzifikaci, čili pestrost

- Zahrada poskytuje velké množství různých zákoutí, různých prostředí a herních prvků.

- Zahrada není omezena jen na anglický trávník a zpevněné povrchy.

- Na zahradě jsou stromy na lezení a klády na cvičení rovnováhy.

- Terén zahrady je svažitý. Děti mají možnost chodit do kopce a s kopce. a v létě či $v$ zimě válet sudy.

- Učí se překonávat přirozené přírodní překážky (kořeny).

- Zahrada je dostatečně členitá a skrývá tajemná místa. 
Pro seznámení se všemi živly

- $\quad$ Na zahradě nebo na místě ze zahrady patrném (na střeše MŠ) je umístěna větrná korouhvička nebo větrná zvonkohra. Děti mají možnost sledovat sílu větru podle zvuku a pozorováním rychlosti otáčení korouhvičky.

- Na zahradě je velké množství nádrží na vodu různých velikostí. Děti mají možnost se seznamovat s živlem voda a také s vodními živočichy.

- Na zahradě je ohniště, které slouží pro slavnostní příležitosti. Děti mají možnost se (při zachování bezpečnosti) seznámit s živlem „oheň".

- Zahrada poskytuje dostatek přiležitostí zkoumat půdní typy. Děti si mohou hrát s blátem či jílem (mají nejen pískoviště, ale i "blátoviště" a "kameniště"). Děti pomáhají nosit zeminu z kompostu ke stromům a květinám. Děti mají možnost kopat a rozšiřovat jámy.

Pro seznámení se živočichy a rostlinami

- Děti mají možnost pozorovat zvířata (např. stínky, hlemýždě, motýly, sarančata, popř. i kočku,králíky či včely).

- Na zahradě je umístěno krmítko a budka pro ptáky. Na zahradě jsou "domečky" pro další druhy živočichů (např. čmeláky, ještěrky, ježky).

- $\quad$ rohu zahrady je kompost.

- $\quad \mathrm{Na}$ zahradě mohou děti nalézt množství různých přírodnin (oblázků, kamenů, šišek, klacíků, dřeva, kůry) a množství různých zajímavých rostlin (fazole a další popínavé rostliny, na dotek citlivou šalvěj či netykavku, žahavé kopřivy, atd.). Důležitá je různorodost a pestrost, jak barev, tak morfologie, tak strategií.

- Děti mají př́ležitost ochutnávat jedlé plody (rybízu, jahod, ostružin, jablek, moruše, oskeruše, kiwi). Děti sbírají zahradní plody.

- Děti se podílí na udržování záhonků květin, bylin či zeleniny. Děti sbírají bylinky a suší je.

\section{Doporučení pro vnitřní prostředí MŠ (třídu, chodby a další vnitřní prostory)}

- Ve třídě visí obrazové tabule (nástěnky) související s EVVO, které jsou vhodně obměňovány.

- Ve třídě nebo na chodbě vystavujeme sbírky přírodnin (kamenů, lastur, motýlů, herbár̆ apod.).

- Ve třídě je možnost separace odpadu, a to minimálně do tří nádob (na papír, na plast, na bioodpad.). Na vhodném místě v MŠ nebo v jejím okolí jsou nádoby na sklo, tetrapack a vybraný nebezpečný odpad (monočlánky, baterie). Tyto nádoby slouží jako sběrné místo, které mohou využívat rodiny dětí.

- Do MŠ učitelky (učitel) nepořizují hračky „na jedno použití”, tj. hračky s krátkou trvanlivostí. Učitelka (učitel) nepřijme každý sponzorský dar, který se jí nabízí. Učitelka (učitel) se snaží o omezení plastových hraček.

- Prostředí MŠ umožňuje dětem i dospělým učit se rozlišovat co je a co není v souladu s pravidly udržitelného rozvoje, potažmo EVVO.

Chov a pěstění 
- Ve tř́idě a na chodbách MŠ pěstujeme vhodně vybrané pokojové rostliny (volíme také druhy pro děti zajímavé, např. masožravé rostliny) a rostliny přenesené z př́rody (např. mechy či sazeničky zeleniny nebo semenáčky stromů).

- Ve třídě chováme třídní mazlíčky, o které děti společně s učitelkou pečují.

Nástroje a předměty k řízené i neřizené nebo ke spontánní aktivitě dětí

- Ve tř́dě jsou dětem $\mathrm{k}$ dispozici lupy pro pozorování.

- Ve třídě jsou dětem k dispozici váhy a závaží pro porovnávání hmotnosti.

- Ve třídě jsou dětem $\mathrm{k}$ dispozici metry, provázky (bužírky) a další pomůcky určené k měření a porovnávání délky.

- Ve tř́́dě jsou dětem $k$ dispozici odměrky na vodu (popř. i písek a drobné předměty) pro porovnávání objemu a množství.

- Ve třídě shromažd'ujeme př́rodniny (obiloviny, luštěniny, šišky, suché rostliny, kůra, lýko) na tvoření výtvarného nebo konstrukčního typu, porovnávání, tř́́dění.

\section{Diskuse}

Vzdělávání a výchova $v$ předškolním věku není v Česku povinně institucializovaná. Dítě může po celé předškolní období zůstávat $v$ péči rodičů nebo navštěvovat nestátní zařízení. Možná $i$ to je jednou z prríčin dřívější nedostatečné pozornosti odborníků oblasti předškolního environmentálního vzdělávání. Přitom ale právě $v$ tomto (předškolním věku) probíhá a je ukončeno tzv. vtištění a upevňování celé řady vzorců chování. Právě tento věk pravděpodobně rozhoduje o budoucích názorech, postojích i o budoucím chování (Strejčková, 2005, Vošahlíková, 2009). Předškolní věk je kritickým obdobím pro rozvoj environmentální senzitivity. Význam rané stimulace a raných zkušeností pro budoucí proenvironmentální chování je uznáván i renomovanými odborníky (OECD, 2006 cit. z Davis, 2009).

Uvědomujíce si klíčový význam tohoto období a zároveň jistou nedostatečnost institucionálního environmentálního vzdělávání, celá řada alternativně smýšlejících rodičů (ekologických aktivistů) neposílá své předškolní děti do mateřských škol a zapojuje je do života rodiny tak, jako to dělaly generace našich předků (srov. Librová, 1994) nebo jako to dělají mnohé národy (srov. Liedloffová, 2007). Rodiče pak mají jistotu, že se dětem dostane dostatečné množství podnětů a kontaktů s př́rodou, mají pod kontrolou vlivy působící na jejich dítě tak, jak to již na začátku 20. století doporučovali stoupenci eubiotické reformy, např. Burbank (1907).

Další skupina rodičů a učitelů zakládá tzv. dětské dopolední kluby, které fungují na bázi lesních mateřských škol (Jančaříková, 2010, Kapuciánová, 2010). Za poslední tř̌i roky jich $\vee C ̌ R$ vznikly tři desítky. Lze se domnívat, že rodiče reagují zakládáním klubů na problém odcizování člověka prírodě. v souladu se zahraničními zkušenostmi Ize totiž u dětí navštěvujících podobná zařízení očekávat nadstandardní rozvoj environmentální senzitivity (Wilke, 1993, Franěk, 2001, Schultz et. al, 2004). Děti, které tráví více času ve venkovním prostředí, mají více príležitostí ke spontánním aktivitám $v$ prírodě či ke kontaktům se zviřaty a také nejsou $v$ tak velké skupině vrstevníků (dospělí jim mohou poskytovat větší pozornost). Ovšem, musíme si uvědomit, že umístit děti do lesního klubu samo o sobě nestačí. Jak zkušenosti několika respondentů ukázaly, můžeme i v lesních klubech najít nebezpečí demotivace, např. z důvodu př́lišného dưrazu na znalosti biologické nebo z opakovaného nedostatku teplotního komfortu. Pak může nastat situace, kdy je environmentální senzitivita a proenvironmentální motivace rozvíjena lépe v MŠ "klasické", než v MŠ "lesní". Úspěch totiž vždy záleží nejvíce na pedagogických pracovnících (učitelkách), jejich znalostech a responsibilitě (srovnej Nováčková, 2003). Proto je osoba 
učitelky neoddělitelnou podstatou úspěšné instucionální realizace environmentální výchovy v předškolním věku (a proto je v našem grafu znázorněna jako jeden ze tří „kořenư"). Ani veliké nadšení pro věc zakladatelů "lesních" MŠ nepomůže, pokud nejsou dodrženy základní podmínky (dítě je několik hodin mokré) nebo zásady environmentální výchovy v předškolním věku (dítě je vystaveno stresu při zkoušení ze znalosti druhư nebo opakovaným neúspěchům v soutěživých hrách). Lze jen doufat, že takové negativní zkušenosti jsou ojedinělé a že naše hnutí lesních mateřských škol se rychle z počátečních chyb vymaní. Snad tomu napomůže, že v MŠ Semínko v Toulcově dvoře probíhá pokusné ověřování lesní MŠ (Lesníček).

Environmentální výchova předškolního věku v ČR se tedy logicky třiští na tři oblasti podle místa, kde předškolní děti tráví čas:

- rodiny (děti nenavštěvují MŠ ani jiné zařízení předškolního vzdělávání),

- dětské dopolední kluby, resp. lesní mateřské školy,

- $\quad$ mateřské školy.

Otázkou je, zda by se environmentální výchova vůbec měla zaměřovat na učitelky v MŠ, které dnes mají v péči až 28 předškolních dětí, zda nebude efektivnější, pokud bude zaměřena na environmentální vzdělávání rodičů, resp. celých rodin (tak to dělají např. v MŠ Slavonice). Strejčková byla přesvědčená, že pro některé děti je lepší navštěvovat státem garantovanou mateřskou školu, než zưstávat celé předškolní období v nefunkční rodině, a že institucializované předškolní vzdělávání má proto smysl. Jak bylo zjištěno v diskusi s učitelkami-expertkami a také ve všech třech ohniskových skupinách, někteří rodiče prostě nejsou dostatečně kompetentní, aby podpořili motivaci dětí k proenvironmentálnímu chování a aby rozvíjeli jejich environmentální senzitivitu a další dovednosti. Kontraproduktivně působí také rodiče, které nutí dítě ke spěchu, místo aby ho nechali pozorovat přírodu či nějakou její zajímavou část a nebo, když dítě oblékají tak, že mu znemožňují volný pohyb a spontánní hru.

Učitelky mateřských škol se učí chápat problematiku environmentální výchovy a výchovy kudržitelnému rozvoji komplexně. Nelze jim vyčítat, pokud se v oboru neorientují, protože neměly dostatečnou odbornou metodickou podporu. Navíc, v závislosti na velkých změnách ve společnosti i na změnách rodinného života, musí učitelky do (nejen) environmentální výchovy zařazovat témata a aktivity donedávna garantovaná rodinami (př́prava pokrmů, práce na zahradě, poznávání domácích zvířat, apod.). Pozitivní je skutečnost, že učitelky MS jsou často pro práci s dětmi zapálené, projevují velkou míru empatie a snaží se rozšiřovat své vzdělání, např. v kurzech Mrkvičky nebo celoživotního vzdělávání či dokonce vysokoškolského vzdělávání v oboru předškolní pedagogika.

Odborníci se shodují na tom, že významným činitelem pro rozvoj environmentální senzitivity je př́roda.

Malaguzzi (1994) používá pro přírodu a informální vzdělávání slovní spojení „třetí učitel" („third teacher"), přičemž prvními učiteli jsou rodiče, druhým učitel či učitelka a třetím prríroda). Právě Malaguzziho pojetíReggio Emilia Approach zřejmě respondenty zásadně ovlivilo při kategorizaci kritérií. Ve skutečnosti je to ale tak, že na rozvoj dítěte a na kvalitu života všech lidí působí každé prostředí, ve kterém se pohybuje. Pozitivně (přírodní, harmonické prostředí), ale i negativně, např. špinavé prostředí neudržovaného panelového domu. Strejčková u nás uvedla v život termín „informální vzdělávání" (Strejčková, 2009), dnes si uvědomujeme, že prostředí lze využívat pro rozvoj environmentální senzitivity i dalších žádaných kompetencí, ale možná nedostatečně upozorňovala na skutečnost, že prostředí nás i naše děti ovlivňuje, i když nechceme. Takže pokud hodnotíme prostředí, nemůžeme hodnotit jen školní zahradu nebo přírodní okolí školy, ale také cestu do školy (Kudy vede? Jde dítě s rodiči pěšky a povídají si při tom?) i vnitřní prostředí mateřské školy (třídu, chodby, sociální zařízení). Vliv prostředí školy na 
psychosociální klima třídy studoval Gislason (2009), i když se nevěnoval přímo environmentální výchově, mnohé z jeho závěrư Ize pro potřeby environmentální výchovy aplikovat. Pokud ve třídě budou děti zaplavené plastovými hračkami, které se rozpadnou na kusy, jakmile se jich někdo dotkne, je něco špatně. a jsou to dospělí, kdo jsou zodpovědní za to, v jakém prostředí se bude dítě pohybovat (Jančaříková, 2004).

Proto je důležité stále si uvědomovat, že nevzniká jen ekologická, resp. environmentální gramotnost, ale také ekologická, resp. environmentální agramotnost (angl. ecologically illiterate), která klíči v nevhodném prostředí a která se projevuje nepochopením toho, jak to $v$ ekosystému chodí, nepochopením potravního retězce, nepochopením adaptace, nosné kapacity prostředí a dalších významných termínů (Barrett, 2001, Orr, 1992, Stamp, 2005 cit. z Balgopal, Wallace, 2009). Kanadští výzkumníci popisují studenty, kteří se do Kanady přisěhovali s rodiči z velkých asijských aglomerací. Nazývají je „padací studenti”, protože tito mladí lidé nejsou schopni chodit bez obtíží po jiném, než rovném povrchu (asfalt, anglický trávník). Na procházce po lesních stezkách klopýtají a padají. Tito studenti neměli v dětství príležitost procházet se po lese. Mnozí z nich $v$ lese $v$ předškolním věku ani nebyli. Jejich rodiče trávili mnoho času v zaměstnání, po práci často navštěvovali různé kurzy. Jací budou tito "padací studenti" rodiči? Pravděpodobně budou upozorňovat své děti, že příroda je špinavá a nebezpečná a že je potřeba se jí vyhýbat. a co horšího - budou své děti učit, že s přírodou je potřeba bojovat a že je potřeba ji zničit a nahradit anglickým trávníkem nebo asfaltem (Bai et all, 2010).

Pozornost posledních let je věnována zahradám mateřských škol. Jak má vypadat zahrada, aby co nejlépe naplňovala potřeby předškolního dítěte? Přehled výzkumů $v$ této oblasti udělala a do tabulky zpracovala Blair (2009).Také vyjmenovává sociální dovednosti a klíčové kompetence, kterých je možné v zahradě získat či rozvíjet, a přehled témat, které je možné na zahradě vyučovat. Pozitivní vliv pobytu na školní zahradě je nepochybný (Blair, 2009).

Názor učitelek, že je vhodné zařazení dalších témat (Zákonitosti a Výzkumné dovednosti) do předškolního vzdělávání, koresponduje s konsensem vědeckých institucí USA, který upozornil, že je potřebné zlepšit přírodovědné vzdělávání (science), a to již v mateřských školách (Fatuyuma, 2007 cit. z Balgopal, Wallace, 2009). Jeden z oponentů ovšem správně poukázal na skutečnost, že by se Výzkumné dovednosti měly nazývat spíše Badatelské dovednosti. v tomto příspěvku z praktických důvodů ponecháváme původní znění.

\section{Závěr}

Příspěvek představuje postup a výsledky kvalitativního šetření. Jeho výstupy by měly nejen přispět k zefektivnění environmentální výchovy v předškolním vzdělávání, ale také se pokusit upoutat pozornost odborné veřejnosti na tuto dosud zanedbávanou věkovou kategorii.

Nejvýznamnějším výstupem je dokument Klíčové oblasti a kritéria realizace environmentální výchovy $\boldsymbol{v}$ předškolním věku, který přináší výčet kritérií environmentální výchovy $v$ předškolním věku. Kritéria byla vztažena ke třem objektům (dítě, učitelka, prostředí) a v rámci výše vypsaných kategoriích řádně popsána a vysvětlena. Autorky dokumentu doufají, že svým počinem napomůžou „zaplňování bílého místa" v oboru a že vzbudí zájem nejen mezi učitelkami a učiteli MŠ, ale i mezi odbornou veřejností. Uvědomují si, že kritéria i jejich zde předložená kategorizace nemusí být konečná, a jsou připraveny je inovovat podle podnětů čtenářù Envigogiky, at' to budou učitelky (učitelé) z praxe i z řad odborné veřejnosti.

Na základě kritérií sebraných v rámci zde publikovaného výzkumu byla napsána kniha Environmentální činnosti v předškolním vzdělávání (Jančaříková, 2010) a vznikl, v této knize publikovaný, Autoevaluační dotazník pro MŠ "Kvalita realizace EVVO". Tato kritéria se stala základem popularizujícího článku $v$ červnovém čísle časopisu Poradce 
ředitelky mateřské školy. Dále byly na Pedagogické fakultě Univerzity Karlovy v Praze v návaznosti na sebraná kritéria aktualizovány předměty Environmentální výchova, Environmentální výchova i a II, Didaktické přístupy k přírodovědnému vzdělávání bakalářského a navazujícího magisterského studia oboru předškolní pedagogika a také otázky ke státní zkoušce ze specializace Environmentální výchova.

Autorky doufají, že - po očekávané diskusi - budou tato kritéria použita jako východisko i v rámci Mrkvičky a dalších kurzů celoživotního vzdělávání pedagogických pracovníků.

Výsledky výzkumu přinesly také zjištění, že u nás došlo v posledních letech v oblasti environmentálního vzdělávání $v$ předškolním věku $k$ celé řadě dílčích kroků vpřed. Jsou to výše popsané publikace a aktivity, ale také jednotlivé maličkosti, které př́mo ovlivňují dění v mateřských školách. Například je dnes běžné používat při pozorování speciální lupy či dokonce mikroskop nebo chovat ve třídě nějaké zvíre. Nesmíme zapomenout na to, že to je jednou z mnoha zásluh Emilie Strejčkové a jejího pevného přesvědčení a činorodosti. Etapa, kdy environmentální výchova v mateřských školách probíhala chaoticky, nebo neprobíhala vůbec, je definitivně za námi.

\section{Seznam použité literatury}

- Arnold, He., Cohen, Fg., Warner, A, . Youth and Environmental Action : Perspectives of Young Environmental Leaders on Their Formative Influences. The Journal of Environmental Education, 40(3), 27-36.

- Bai, H., Elza, D., Kovacs, P., \& Romanycia, S. (2010). Re-searching and re-storying the complex and complicated relationship of biophilia and bibliophilia.Environmental education research, 16(3-4), 351-365.

- Balgopal Mm., Wallace, A., (2009). Decision and Dilemmas : Using Writing to Learn Activities to Increase Ecological Literacy. The Journal of Environmental Education, 40(3), 13-26.

- Benešová, V. (2010). Korálky poznání : Průvodce (nejen) naučnou stezkou. Celoroční projekt EVVO. Slavonice: Mateřská škola Slavonice.

- Blair, D. (2009). The Child in the Garden : An Evaluative Review of the Benefits of School Gardening. The Journal of Environmental Education, 20(2), 39-95.

- Burešová, K. (ed.), (2007). Učíme se v zahradě. Chaloupky.

- Burbank, L. (1907). Training of the Human Plant. New York: Century.

- Corbett, J. (2006). Chrámový tygr. Volary: Stehlík.

- Činčera, J. (2009). Analýza průřezového tématu Environmentální výchova v Rámcovém vzdělávacím programu pro základní vzdělávání. Envigogika, 4(1), Retrieved from http://envigogika.cuni.cz/index.php/cs/texty/20091

- Č̌inčera, J. (2007). Environmentální výchova : Od cílů k prostředkům. Brno: Paido.

- Činčera, J. (2010). Doporučené očekávané výstupy pro environmentální výchovu. Envigogika, Retrieved from http://www.envigogika.cuni.cz/index.php/cz/component/content/article/183-recenzovaneclanky/envigogika-2011vi2/581

- Davis, J. (2009). Revealing the research "hole" of early childhood education for sustainability : a preliminary surfy of the literature. Environmental Education research, 15(2), 227-241.

- Franěk, M. (2001). Potřeba dětské hry v přirozeném prostředí. Psychologie dnes, 4, 14-15. 
- Franěk, M. (2004). Psychosociální faktory ovlivňující úspěšnost environmentální výchovy. Praha: Český ekologický ústav, oddělení environmentálního vzdělávání, výchovy a osvěty.

- Gislason, N. (2009). Mapping School Design : A Qualitative Study of Relations Among Facilities Design, Curriculum Delivery, and School Climate. The Journal of Environmental Education, 40(4), 3-15.

- Gründler, Ec., Schafer, N., (2010). Dětská hřiště a zahrady v prírodním stylu : Význam, plánování, realizace. Praha: MŽP.

- Horká, H. (1996). Teorie a metodika ekologické výchovy. Brno: Paido.

- Jančaříková, K. (2008). Environmentální výchova na prvním stupni ZŠ. Praha: UK-PedF.

- Jančaŕíková, K. (2007) Environmental education in the elementary schools. In Czudar, A., István, I., Tóth, A (Ed.), 5th International JTET conference on theories and practices for education od sustainable development (pp. 161-172). Debrecín: Acta pericemonologice Debrecina.

- Jančaříková, K. (2010). Pedagogika pod širým nebem. Sedmá generace, 19(1), 10-13.

- Jančaříková, K. (2010). Environmentální činnosti v predškolním vzdělávání. Praha: Josef Raabe.

- Jančaříková, K. (2009). Hledání optimální podoby realizace environmentální výchovy na prvním stupni ZŠ. Envigogika, 4(1), 1-9. Retrieved from http://www.envigogika.cuni.cz/index.php/cs/texty/20091/298-hledani-optimalni-podobyrealizace-environmentalni-vychovy-na-prvnim

- Kapuciánová, M. (2010). Lesní mateřské školy. Diplomová práce. Praha: UK.

- Kopřiva, P. aj, (2008). Respektovat a být respektován. Kroměříž: Spirála.

- Leblová, E. (2012). Environmentální výchova v mateřské škole. Praha: Portál.

- Librová, H. (1994). Pestří a zelení : Kapitoly o dobrovolné skromnosti. Brno: Veronica, Hnutí Duha.

- Liedloffová, J. (2007). Koncept kontinua : Hledání ztraceného štěstí pro nás a naše děti. Praha: Dharma Gaia.

- Máchal, A. (2000) Ekopedagogovo osmero. In Průvodce praktickou ekologickou výchovou. Brno: Rezekvítek, Lipka.

- Malaguzzi, L. (1994). The hundred languages of children. The Reggio Emilia Approach to Early Childhood Education. Norwood, NJ: Ablex Publishing. Municipality of Reggio Emilia Infant-To. Retrieved from http://home.hanmir.com/ leekid2/sa5.html

- North American Association For Environmental Education (naaee), (2010). Early Childhood Environmental Education Programs : Guidelines for Excellence. Washington, D.C. 20036 USA: NAAEE Publications and Membership Office.

- Nováčková, J. (2003). Mýty ve vzdělávání : O škodlivosti některých zaběhaných představ o učení, škole a výchově. Kroměříž.

- Pastorová, M. a kol, (2011). Doporučené očekávané výstupy. Metodická podpora pro výuku průřezových témat na základních školách. Praha: Výzkumný ústav pedagogický. Retrieved from http://www.vuppraha.cz/nova-publikace-divize-vup-\%E2\%80\%93-doporuceneocekavane-vystupy-pro-zakladni-skoly

- PAVUČINA. Sdružení středisek ekologické výchovy Pavučina [online] . . Retrieved from http://www.pavucina-sev.cz

- $\quad$ Reid, A., Scott, W., . Researching education and the environment : Retrospect and prospect.. 
- Environmental Education Research (2006). . Environmental Education Research, 12(3-4), 117.

- Schultz, P. W., Shriver, C. H., Tabanico, J. J., \& Khazian, A. M. (2004). Implicit connections with nature. Journal of Environmental Psychology, 24(1), 31-42. Retrieved from http://linkinghub.elsevier.com/retrieve/pii/S0272494403000227 http://dx.doi.org/10.1016/S0272-4944(03)00022-7

- Strauss, A., \& Corbin, J. (1998). Basics of Qualitative Research : Techniques and Procedures for Developing Grounded Theory.. London.

- Strauss, A., \& Corbinová, J. (1999). Základy kvalitativního výzkumu. Brno: Podané ruce.

- Strejčková, E. (ed.), (2005). Děti, aby byly a žily.. Praha: MŽP ČR.

- Takano,t., , Higgins, P., \& McLAUGHLIN, P. (2009). Connecting with place : implications on integrating cultural valuews into the school curriculum in Alaska. Environmental Education Research, 15(3), 343-370.

- Uhříčková, A. a kol, (1996). Korálky II. Brno: EkoCentrum.

- Uhříčková, A. a kol, (1997). Korálky III. Brno: EkoCentrum.

- Vošahlíková, T. (2009) Role předškolního vzdělávání ve výchově k udržitelnému rozvoji. In Činčera et al. (Ed.), Člověk + príroda = udržitelnost? : Texty o proměně vztahu lidí $k$ prírodě, environmentální výchově a udržitelnosti. Praha: Zelený kruh.

- Wilke, R. J. (ed.), (1993). Environmental education : Teacher Resource Handbook: A practical Guide for K - 12 Environmental Education. Thousand Oaks, California: Corwin press.

- Rámcový vzdělávací program pro předškolní vzdělávání (2004). Praha: Výzkumný ústav pedagogický v Praze. Retrieved from http://www.vuppraha.cz/

PhDr. Kateřina Jančaříková, Ph.D.

Mgr. Magdaléna Kapuciánová 
Časopis Envigogika vydává Centrum pro otázky životního prostředí UK. Vývoj časopisu je podpořen projektem OP VK Mezioborová sít udržitelného rozvoje.

Více najdete na internetových stránkách projektu http://mosur.czp.cuni.cz
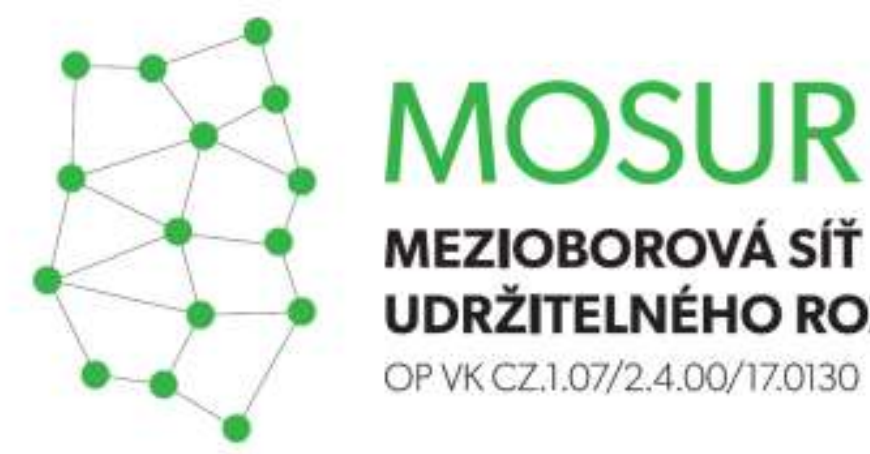

\section{MEZIOBOROVÁ SÍT}

UDRŽITELNÉHO ROZVOJE

OP VK CZ.1.07/2.4.00/17.0130
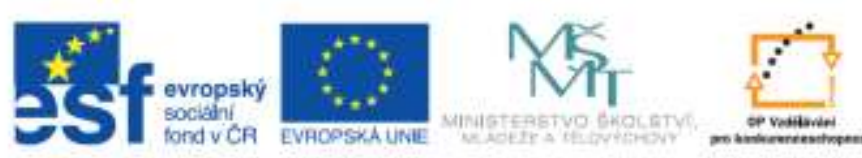

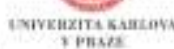

INVESTICE DO ROZVOJE VZDELAVANI 